\title{
Politics of alliances and its effects during Zulfiqar Ali Bhutto's rule in Pakistan
}

\author{
Ulfat Zahra* | Javed Iqbal \\ Department of History, Faculty of Arts \& Humanities, University of Peshawar, Peshawar, Pakistan. \\ * Correspondence Email: ulfatzahra120@gmail.com
}

\begin{abstract}
The paper mainly focuses on political alliances during the rule of Zulfiqar Ali Bhutto. This study is based on the opposition's struggle in the form of political alliances to counter Bhutto's absolute power. The period thus saw the emergence of opposition alliances such as the United Democratic Front, the Pakistan National Alliance to organize resistance against Bhutto's rule. However, this trend has not been limited to opposition's alliances only. At times, the government joined hands with the opposition and major parties to achieve an agreed objective. In this study, a descriptive analysis is employed to cover the main theoretical and political formations of accords between the opposition and the ruling party. These unnatural alliances between political parties had immense effects on the future political scenario of Pakistan. It has also been observed that the opposition's alliances, left behind their imprints on the history of Pakistan leading to the imposition of martial law in 1977 and changing the course of political events ever since. The findings will demonstrate that the political parties were engaged in a struggle for the preservation of the personal ambitions of party leaders. If they tackle the situation with harmony, a firm democracy can establish in Pakistan.
\end{abstract}

\section{Article History}

Received:

November 3, 2020

Last Revised:

January 1,2021

Accepted:

January 5, 2021

Published:

April 18, 2021

Keywords: democracy, elections, provincial autonomy, political parties, alliances, political alliances, political opposition, oppositions parties, politics in Pakistan.

\section{How to Cite:}

Zahra, U., \& Iqbal, J. (2021). Politics of alliances and its effects during Zulfiqar Ali Bhutto's rule. Liberal Arts and Social Sciences International Journal (LASSIJ), 5(1), 89-104. https://doi.org/10.47264/idea.lassij/5.1.7

Publisher's Note: IDEA PUBLISHERS (IDEA Journals Group) stands neutral with regard to the jurisdictional claims in the published maps and the institutional affiliations.

Copyright: () 2021 The Author(s), published by IDEA PUBLISHERS (IDEA Journals Group). This is an Open Access article published under the Creative Commons Attribution-NonCommercial 4.0 International License (http://creativecommons.org/licenses/by-nc/4.0/) 


\section{Introduction}

This study aims to thoroughly investigate the real factors behind the formation of various alliances during the rule of Zulfiqar Ali Bhutto to determine the merit and genuineness of their involvement in the political campaigns that led to the fall of the government in July 1977. Many political analysts and scholars have contributed valuable works, such as books, dissertations, and articles, etc. on this subject from various perspectives. Despite its limitation to the Bhutto era, the present research has filled gaps in the understanding of the theory and practice of political alliances and their future political implications. It also deals with the dynamics and objectives of unnatural alliances between diverse and opposing political groups in opposition and between government and opposition to topple regimes or prolong their duration. In each case, national interest is undermined and compromised.

The formation of political alliances is not a new phenomenon in Pakistan's political history. Since her inception, politics in Pakistan has witnessed alliances between political actors, sometimes with opposite outlooks and manifestos. The dynamics of opposition alliances during military and democratic regimes were the inability of the opposition parties to contest the authority of the ruling party alone. They, therefore, resorted to politics of alliances based on minimal common objectives and minimum points of agreement, at times compromising upon their party interests and manifestos. These alliances were considered as the marriages of convenience between opposing groups for short-term gains. As goals, conditions, and realities changed, the alliances ended in chaotic ways or the allies split up and adopted their positions under the changed political circumstances. Unfortunately for most of the time, the powerful and ambitious political personalities, rather than political ideologies and party platforms, have been the dominant factors in the formation of alliances and coalitions. The masses have cooperated with all these political alliances in the history of Pakistan with different intensity, seeking to promote democracy and to redress public grievances against the government of the time, but politicians often abandoned their declared objectives and erratically betrayed public trust once the immediate goal was achieved. The consequences were thus almost always negative and harmful, not strengthening democratic values but derailing the system itself.

The formation of alliances against the Muslim League governments and the defeat of the ruling party by the United Front in the 1953 elections in East Pakistan were the first manifestations of the tendency towards alliances between the opposition parties to dislodge political authority in Pakistan. The formation of the National Awami Party in 1957 (composed of various parties in East and West Pakistan) and the subsequent political manoeuvring among parties led to the overthrow of several ministries in Pakistan both at the central and provincial levels. A little later, the formation of the Combined Opposition Parties in 1964, the candidacy of Mohtarma Fatima Jinnah against General Ayub Khan in the presidential elections, the formation of the Pakistan Democratic Movement under Nawabzada Nasrullah Khan, and its transformation into the Democratic Action Committee are just a few examples from Pakistan's early political history all of which were typical type of the alliance between opposition parties to challenge the ruling authority of the time. Though, many of these alliances have acted as a driving force to unite the political forces and the masses against the dictators, forcing them to relinquish the power and pave the way for democracy yet, that was not always the purpose or spirit behind the alliances in Pakistan.

After the fall of Dhaka in 1971, Political alliances or accords are the most common phrases that we come across in the era of Zulfiqar Ali Bhutto. The beginning was promising and 
positive. The politicians from West Pakistan, belonging to different political parties and backgrounds, joined hands to secure the area of what remained of Pakistan. The Pakistan People's Party was graciously allowed to continue as the ruling party at the centre. In the provinces too, the democratic process had a promising beginning. In the absence of an electoral majority of Pakistan People's Party in Baluchistan and North-West Frontier Province, the NAP-JUI coalition formed their ministries and the two provinces soon emerged as the stronghold of political opposition in the country.

The unanimous passage of the first-ever social contract in the shape of the 1973 constitution is the best example of a constructive alliance between the PPP, NAP, and JUI, who signed a Tripartite Accord to become allies in the drafting of a unanimous constitution for the country. But soon after this brief honeymoon period, Bhutto got indulged in power politics of the worst kind while the opposition parties started politics of alliances to dislodge the incumbent political regime in the country. The subsequent tug of war caused the dissolution of NAP-JUI coalition governments in NWFP and Balochistan with disastrous consequences. Both these provinces experienced armed insurrections and the worst law and order situation in the years that followed the dissolution of the NAP-JUI coalition ministries. The diversified political groups in the opposition joined hands and launched alliances like the United Democratic Front (UDF) and the Pakistan National Alliance (PNA) to counter the attempts of Bhutto at establishing a sort of civilian dictatorship. Bhutto was encircling them from all sides and they had to fight a battle of political survival.

These alliances were formed to gain the support of different segments of society. The UDF was formed by eight leading political parties to confront Bhutto and his authoritarian policies. However, due to their mutual rivalries and lack of understanding, the opposition parties did not succeed in forming an effective bloc and their joint efforts could not pose a significant challenge to Bhutto. In another attempt to curb Bhutto's fierce and unbridled power, the political parties reunited to form the Pakistan National Alliance (PNA) and decided to contest elections from a single platform. However, the shocking election results turned the electoral alliance into a movement for the removal of Bhutto from power. The confrontation between the two sides culminated in the unfortunate events of July 1977 when General Zia ul Haq imposed martial law in the country.

The paper aims at appending and analyzing the immediate and long-term effects of political alliances in the light of the available information about the political developments in the period under study. Political alliances may lead to political chaos and enticement to the undemocratic forces to usurp political authority and establish dictatorship or they may result in a strengthening of the democratic system and promotion of democratic values, making a country stable and strong. In Pakistan, political alliances for temporary political gains with a disruptive approach have so far qualified to be placed in the first category because for most of the time they were woven around selfish personal or party interests instead of public wellbeing and national interest.

\section{Theoretical framework}

The political alliances have played a key role in the context of the political system of Pakistan. The pre-election alliances and post-election coalitions governments (based on the election results) among political parties have always remained an important feature of Pakistani politics. To re-evaluate the political alliances in the view of their theoretical background the theories of 
size and ideology and the new institutionalist theory of coalitions are applied to this study (Kadima, 2014).

The coalition theories that are based on size and ideology originated in the 1960s and 1970s tend to focus on the impact of prospective coalition formation, opportunities and can be divided into "office-seeking" and "policy-seeking" theories, based on the belief that the main goal of political parties is to gain access to power. These theories are based on the assumption that government coalitions should consist of a few political parties as much as possible, just enough to win the legislature's vote of confidence on the one hand, while also persuading opposition parties to control the government by forming alliances of like-minded parties on the other (Leiserson, 1968).

It is therefore convincing that the key points of the theories on office-seeking and winning the majority of seats in the legislature and putting pressure on the ruling party by the opposition parties are relevant and applicable in the context of Political alliances in Pakistan. 'Office Seeking' is a desire to gain access to power and to win the majority vote in the legislature. Therefore, in this case, this theory applies because Bhutto made two accords with the NAPJUI to gain his objectives of vital importance like the vote of confidence in the National Assembly and the approval of the constitutional draft. Similarly, the alliance between the NAP and the JUI, though they were pursuing almost opposing ideologies, yet agreed to cooperate out of sheer political necessity, to gain power and ministries in Baluchistan and Khyber Pakhtunkhwa (then NWFP).

The 'opposition political alliances' refer to the formation of an alliance between parties of similar persuasion to control governments and ensure the preservation of national interests to their mode of operation or through implementation. It is also relevant to the subject understudy in the framework that the politicians had many disagreements among themselves yet they succeeded to strengthen their position against Bhutto and formed alliances of disruptive nature in the form of the United Democratic Front and Pakistan National Alliance to achieve their ulterior motives by pressurizing the ruling party. Hence, the study examined all kinds of productive and disruptive nature of political and electoral alliances during the Bhutto era in detail. Therefore, this work is a modest step towards understanding the formation of alliances and coalitions before and after elections and their impacts on national constancy and party politics during the Bhutto rule.

\section{Research methodology}

In this study, a combination of qualitative, analytical, and survey research methods is applied. Both the primary (unpublished manuscripts, contemporary newspapers, etc.) and secondary sources (books, journals, articles) of information have been utilized for this study. To evaluate facts based on available data, analytical and descriptive methods have been applied. To assess some other relevant aspects, a survey method of research has been applied by conducting personal interviews i.e., recording, and handwritten notes, distributing semi-structured questionnaires, and exchange of emails with significant political figures. The output of this study could be used as a dependent variable to conduct both qualitative and quantitative research by other researchers for further research on this topic. For the data collection, the Directorate of Archives \& Public Library Peshawar, libraries of various institutions as well as Internet sources were found to be very helpful. The content analysis method has been used to analyze the collected data. 


\section{The politics of alliances in the Bhutto Era: A discussion}

After the separation of East Pakistan as an independent Bangladesh, the Pakistan People's Party was the only majority party in the remaining of Pakistan. It had won an absolute majority in the Punjab and Sindh provinces but was virtually non-existent in Balochistan and North West Frontier Province (now Khyber Pakhtunkhwa). It got only one National Assembly seat from NWFP while three out of forty seats in the NWFP Assembly and none in Balochistan, where the National Awami Party led by Khan Abdul Wali Khan and Jamiat Ulama I Islam of Maulana Mufti Mahmud won the majority seats (Khan, 2002). It was under these circumstances that Bhutto assumed power and became the President and Chief Martial Law Administrator of Pakistan on December 20, 1971 (Niaz, 2010).

On assuming powers, Z. A. Bhutto realized the problems faced by Pakistan and appealed to the political parties for cooperation in his first address to the nation. He made a conciliatory gesture towards these parties by removing the ban on the National Awami Party (NAP), imposed by Yahya Khan on 26 November 1971 because the NAP had strongly opposed and condemned military action in East Pakistan, insisting on a political solution to the issue (Firdausi, 1988; Sherpao, 2017).

This signal of flexibility created a pleasant atmosphere and Wali Khan welcomed Bhutto's speech and responded to his conciliatory approach by offering his party's unconditional support. Bhutto went further and invited Wali Khan for negotiations (Raza, 1997). Thus, an era of warmth and goodwill between the ruling party and the opposition began to develop in the greater interest of the nation (Tasneem, 2013).

\subsection{PPP-NAP-JUI alliance (the tripartite accord)}

In the 1970 parliamentary elections, the NAP turned out to be an important and influential opposition party at the national level and the largest political party in the provincial assemblies of NWFP and Balochistan. (Sufi, 2017) Despite his ambitious nature, Bhutto was also a political genius. He had realized that side-lining the NAP-JUI leadership in NWFP and Balochistan would neither be possible nor productive as he needed their support in the National Assembly for the approval of the constitutional draft. He thus realized the importance of NAPJUI support (Raza, 1997; Alvi, 2016). He, therefore, made two accords with the NAP and JUI, one on March 6, 1972, and the other on April 27, 1972 (Dawn, 1972).

Ultimately, because of practical considerations, Bhutto invited leaders of NAP and JUI to Islamabad to resolve differences and evolve a consensus on national issues. The meeting was attended by notable leaders like Wali Khan, Mir Ghaus Bakhsh Bizenjo, Arbab Sikandar Khan Khalil, Nawab Khair Bakhsh Marri, Mufti Mahmud, Maulana Ghaus Hazarvi, Ghulam Mustafa Jatoi, Abdul Hafeez Pirzada, Maulana Kausar Niazi, Rafi Raza, and Hayat Sherpao. (Hussain, 2000) As a consequence of three days negotiations, Bhutto signed a twelve-point accord, Wali Khan, and Mufti Mahmud on March 6, 1972. The agreement was known as the 'Tripartite Accord;' and Bhutto personally announced its details on Radio Pakistan (Dawn, 1972).

The Tripartite Accord resolved the political and constitutional deadlock in Pakistan and was welcomed by many politicians including Sardar Shaukat Hayat Khan, president of PML (Council), M. Zafar, former central Law Minister, and the Advisor to the leaders of the National Awami Party, Mr. Ahmad Raza Kasuri, Chairman of the Pakistan People's Party (Progressive 
Group), Maulana Ubaidullah Anwar, Chief of the Jamiat Ulma-e-Islam, Maulana Abdul Hakim and Maulana Shah Ahmad Noorani. They considered the accord as an act of statesmanship on the part of the three leaders i.e., Bhutto, Wali Khan, and Mufti Mahmud. Wali Khan had also endorsed the accord while addressing a public meeting at Charsadda and considered the accord essential for the integrity and solidarity of Pakistan (Amin, 1974). Consequently, Bhutto decided to lift martial law and made this announcement on April 14 at the session of the National Assembly (Dawn, 1972).

The agreement gave a formal consent of the federal government to the formation of the NAPJUI coalition ministries in NWFP and Balochistan (William, 1975). The most important point included in the accord was an acknowledgment of the NAP-JUI demand by Bhutto government that governors should be appointed in the provinces in consultation with the majority party (Siddique, 2014).

Arbab Sikandar Khan Khalil and Ghaus Bakhsh Bizenjo were appointed as Governors of NWFP and Balochistan respectively on April 29, 1972, and Attaullah Mengal and Mufti Mahmud were sworn in as Chief Ministers of Baluchistan and NWFP respectively on May 1, 1972, while Wali Khan was appointed leader of the opposition in the National Assembly of Pakistan (The Pakistan Times, 1972). Further, the National Assembly passed an "Interim Constitution," on April 17, legitimizing Bhutto's authority as President of Pakistan. While Martial Law was lifted, the state of emergency, however, remained in force (Baxter, 1974; Malik, 2020).

Therefore, for the first time, a setup in which the Pakhtun and Baloch leaders could play a commanding role was established with the formation of NAP-JUI governments in the Frontier and Balochistan and by appointing Wali Khan the opposition leader in the National Assembly. This was a part of the constitutional understanding that the central government under Bhutto reached with the NAP-JUI leadership (Sayeed, 1985; Tasneem, 2013).

The accord between Bhutto and NAP-JUI leadership was just one instance of Bhutto's greater intellect and political sagacity. He needed their support not just for constitution-making but for other objectives of vital importance like agreement with the International Monetary Fund (IMF) and settlement with India. In academic discourse, one should not be judgmental here about Bhutto's intentions but later developments indicate that he accommodated the opposition's point of view and allowed these parties to govern for a few months in Baluchistan and NWFP only to secure his position and achieve his immediate objectives (Haidar, 1996; Shah \& Khan, 2012).

\subsection{New instance of alliances: The NAP-JUI coalition}

In the era under study, different political parties with divergent manifestoes and ideologies joined hands with each other just to make their political survival possible and to gain absolute power. The first instance in this regard worth mention here was the alliance between NAP and JUI. Even though both parties had pursued very different and almost opposing ideologies, they felt the need to cooperate to gain power and ministries (Hussain, 2008).

Initially, an alliance was expected from the PPP and the NAP, as it was believed that the leftist parties like the NAP would be a more natural ally of the PPP due to their similar ideological stance and its accommodation into the political system of Pakistan. But in reality, there were 
fundamental differences between the two parties. The NAP, founded in 1957, was an openly secular and socialist platform of radical Baloch, Sindhi, Pakhtun, and Bengali nationalists. It perceived itself as a more seasoned left-wing party as compared to the PPP but Wali Khan had to give up socialism and secularism and swung inevitably to the right to ally with the JUI in NWFP and Balochistan to form coalition ministries (Mahmood, 2000).

Before the 1970 general elections, both NAP and JUI leadership did not have cordial relations or any common grounds for a coalition. They contested fiercely on several seats in the Pakhtun populated regions. However, the results of the election necessitated cooperation between the two and consequently both the parties decided to ally the two provinces (Williams, 1975). Here, it is desirable to have an overview of both NAP and JUI as political parties since their inception to understand the strange and unusual alliance.

The NAP leadership and politics were greatly influenced by the political doctrine and program of Khudai Khidmatgars, which had remained a strong supporter of provincial autonomy since 1947. Its leadership followed a socialist program and favoured a constitutional setup with the minimal role of the Centre, having control over only three subjects namely, defense, foreign affairs, and currency. (Kumar, 1978) On the other hand, Jamiat Ulam-i-Islam was a religious political party having a strong support base in Pakhtunkhwa and Balochistan. Its leadership was the follower of the Deoband school of thought having vast political experience. The major agenda of the party was the implementation of a political system based upon the Sharia and Sunnah of the Holy Prophet. (Ahmad, 1993) The party opposed socialism and contested the elections of 1970 on a manifesto that included the implementation of the Islamic political system in the country. Despite some fundamental ideological differences with the NAP, the party was forced by the circumstances to ally with NAP to form coalition governments in NWFP and Balochistan (William, 1975).

Because of the party position in the Balochistan and NWFP, the Muslim League Qayyum Group and the NAP were not in a condition to set up a government without the support of the JUI. Therefore, Mufti Mahmud clarified his stance and expressed his views in a press conference, declaring that he would make coalition ministries with the party that was prepared to elect him as Chief Minister of the NWFP (Mazari, 1999). Mufti Mahmud also presented a formula and offered to form a coalition with any of the parties who had a substantial presence in the province (NAP and PML Qayyum) on the following conditions:

a) Concerning the constitution-making process, the ally party would support the JUI's position;

b) Provincial governments would strictly comply with Sharia laws to the extent permitted by the restrictions they impose;

c) To bring existing laws into conformity with the Quran and Sunah, a council of Ulama should be established;

d) Establishment of another council for the growth of industry and forestry;

e) Provide moral training to students in educational institutions.

This formula presented by Maulana Mufti Mahmud was accepted by the NAP leadership that brought them together. Both parties agreed to support each other to form the coalition governments in Balochistan and NWFP. The JUI chose to support the NAP instead of PML(Q) because of its prominent role in the politics of Pakistan. NAP was also considered politically more reliable than the PML $(\mathrm{Q})$ because the coalition with the PML(Q) would only guarantee 
power-sharing in NWFP because there was no chance for the PML(Q) to form the government in Balochistan (Pirzada, 2000).

It was quite ironic that both the parties followed differently and, in many aspects, almost opposite ideologies yet they agreed to cooperate out of sheer political necessity. This unnatural alliance, therefore, is best described by the sarcastic but appropriate term 'a marriage of convenience' (Sherpao, 2017). Mufti Mahmud himself admitted the fact that he joined hands with the NAP for the only reason that the latter accepted his five-point formula of compromise (Mahmud, 1972).

After the alliance between NAP and JUI, Wali Khan acted with caution to minimize and avoid the risk of any conflict with Mufti Mahmud. He maintained pleasant relations with JUI and was at times flexible to the extent of compromising his party's agenda to keep the alliance intact and workable (Wriggins, 1975).

\subsection{Bhutto-Qayyum alliance}

Before the 1970 elections, Abdul Qayyum Khan had offered his cooperation to Abdul Wali Khan and was ready to accept his leadership in a joint election campaign but the latter had declined any alliance with him due to his record of hostile actions against Ghaffar Khan and his family. This turned Qayyum Khan more hostile towards the NAP leadership and started propaganda against them for their pre-partition political stance and their opposition to the creation of Pakistan. (The Pakistan Times, 1971). Therefore, Bhutto's attempt of conciliation with NAP-JUI leadership was not liked by Khan Abdul Qayyum Khan, Bhutto's ally in NWFP. He was an arch-enemy of Wali Khan and did not like the importance was shown to NAP in the Centre. He suggested that the Muslim League Qayyum, the PPP, and the independents could join hands to obtain a majority in NWFP Assembly. The ongoing negotiations of PPP with Qayyum Khan were meant to pressurize the NAP-JUI leadership on the constitutional issue (Raza, 2001).

Bhutto was anxious about Wali Khan's growing popularity as the national leader of a clique equal to his own. To counter the growing popularity and strength of the NAP and the NAP-JUI axis, Bhutto aligned himself with the anti-NAP feudal and reactionary elements and entrusted some of them with important portfolios within the federal cabinet. He finally decided to enter a pact with Khan Abdul Qayyum Khan (Kaushik, 1985). A compromise was reached with Qayyum Khan and he was appointed as a Central Interior Minister in the federal cabinet, which undermined an earlier agreement between Bhutto and his political rivals, the NAP-JUI leadership (Alvi, 2016).

Thus Bhutto pursued a double policy: on the one hand, he entered into an alliance with NAP and JUI and allowed the formation of coalition governments in the provinces of Balochistan and NWFP only to give the impression that he was fulfilling his democratic and constitutional obligation to the leaders of NAP-JUI, and on the other hand, he included the anti-NAP elements in the Federal Government to create problems for their governments in the two provinces and to strengthen Wali Khan's political rivals (Kaushik, 1985).

During this period, Abdul Qayyum Khan played a negative and subversive role in the national politics, preventing national cohesion and rapprochement between Z. A. Bhutto and NAP leadership for his ulterior motives. As the Interior Minister, he had easy access to all the police 
and intelligence reports and by exaggerating these reports about Wali Khan's domestic activities and foreign visits, he tried to create misunderstandings between Bhutto and Wali Khan (Sufi, 2017).

In doing so, he also expected to gain the support of the landless poor tenants against the land owing Khans in the strong support base area of NAP, i.e., Peshawar, Mardan, and Charsadda (Amin, 1988). In this way, Wali Khan's suspicions of Qayyum Khan and Bhutto's intentions and Bhutto's fear of his rising popularity led to a clash of personalities that had its impact on national as well as provincial politics of Pakistan.

\subsection{The United Democratic Front (UDF)}

The year 1973 was perhaps one of the most critical years in the political history of Pakistan. The dismissal of a democratically elected provincial government and the army action in Balochistan coupled with the resignation of Mufti Mahmud's cabinet in NWFP intensified the wave of protest against the Bhutto regime by the opposition. In such an unpleasant atmosphere, the opposition political parties realized that it was a time to unite for their political survival and to face the PPP from one platform. All opposition parties of the country to put more pressure on the ruling party to make amendments to the draft constitution met at a convention on February 28 - March 1, 1973, in Rawalpindi and formed the United Democratic Front (UDF) on 13 March 1973, which criticized the draft law as undemocratic and un-Islamic (Ahmad,1990)

The leaders of the opposition parties gathered at Chaudhry Zahoor Elahi's house and finally declared the formation of the United Democratic Front (UDF). The UDF consisted of eight political parties, including; National Awami Party, Pakistan Muslim League, Jamiat Ulama-iIslam, Jamiat Ulama-i-Pakistan, Pakistan Democratic Party, Khaksar Tehrik, Jamaat-i-Islami, and the independent members of National Assembly. Syed Mardan Ali Shah Pir of Pagara and Mufti Mahmud were elected as its President and vice-president respectively, while Professor Ghafoor Ahmad became the General Secretary and Wali Khan was elected as the Convener of the Front (Wolpert, 1991).

The UDF's declared objectives were to safeguard and protect the country's geographical entity and unity, struggle for the implementation of the Islamic Democratic Federal parliamentary constitution in the country, and efforts for provincial autonomy. (Anjum, 1993) The other demands comprised the restoration of the democratic and constitutional rights of the people, the withdrawal of troops from Balochistan and the lifting of the state of emergency, the release of political prisoners, freedom of the press, and the swift promulgation of the constitution. (Hussain, 2008) They also demanded general elections within six months of the passing of the constitution and handing over the country to a caretaker government. Two of their demands were of fundamental importance; Article 2-A proclaiming "Musawat-e-Muhammadi" as the guiding principle of the economy of Pakistan and constitutional guarantees for private property (Ziring, 2003).

The unity of the opposition parties during this period seemed to be an important political development in the history of Pakistan. When most of the UDF-sponsored amendments to various constitutional provisions were rejected by the government, it resulted in the war of words, and violent clashes between the government and opposition members in the National Assembly; and became more intense and frequent with time. Due to the increasing temper of 
the opposition parties, the 'National Convention' of UDF was called in Lahore in the first week of August 1973. They showed bitterness over the attitude of Z. A. Bhutto and his delaying strategies in implementing the permanent constitution. The UDF leaders announced to launch of the 'Civil Disobedience Movement' and pledged to continue till the approval of their demands (Kumar, 1978).

The meetings were organized by the UDF in various parts of the country. The government issued orders for the arrests of some key leaders of UDF. The UDF leaders observed "Black Friday" to protest against Bhutto's authoritarian tactics and held a public meeting at Liaqat Bagh Rawalpindi on 23 March 1973 on the occasion of Pakistan Day (Hussain, 2008). But the gathering was subjected to an organized attack by armed PPP workers and the Federal Security Force, turning the Liaqat Bagh and the surrounding localities into a battleground with bullets flying and exploding tear-gas shells. Many workers were killed and injured (Khan, 2005). This undemocratic act of $Z$. A. Bhutto was criticized by the opposition parties and UDF announced the boycott of the National Assembly session as a protest after the Rawalpindi incident (Mahmood, 2000).

Realizing the importance of the UDF and the need to lower the political temperature, Bhutto invited the opposition leaders to a meeting and succeeded in reaching an agreement with them before the National Assembly session scheduled for April 10. Bhutto accepted many logical and reasonable demands of UDF that he had rejected for the past six months. He showed extraordinary leniency towards the major Islamic parties including, JI, JUI, and JUP, and accepted their demands of the President and Prime Minister to be Muslims, arrangement, and facilities for the teaching of Arabic language and the printing of correct flawless version of Holy Quran throughout the country. (Wolpert, 1991) This was another fine example of going back on a party's declared agenda of a secular nature and accepting pure religious demands just to appease the rival political leadership.

Moreover, the NAP leadership was probably convinced that it would be better to make Bhutto accept some of their demands concerning the sharing of powers between the centre and the provinces rather than to boycott the session of the National Assembly that was to finalize and approve the permanent constitution of the country and let the ruling party frame a constitution of their liking (Burki, 1988). Wali Khan and his associates probably had also realized that if they wanted to achieve national stature and gain the support of Punjab and Sind then they would have to show flexibility in their traditional and long-established stand on the subject of provincial autonomy (Mahmood, 1988; Khan et al., 2017).

Later on, all the political parties set aside their opposition and decided to participate in the constitutional proceedings on the appeal of the Law Minister. This was a turning point in Pakistan's political and constitutional history. Bhutto exhibited greater leniency by accepting a few more of the UDF demands. On 12 April, Fazal Elahi Chaudhry, the speaker, presented the President with the final draft constitution, which was passed unanimously by all political parties without any dissenting vote (Malik, 2020).

Though the political parties included in the UDF had many disagreements among themselves yet they succeeded in making Z. A. Bhutto incorporate their demands in the 1973 Constitution. Z. A. Bhutto had also realized that he could not cope with all these independent movements having strong roots in the Frontier province. Despite all his efforts to get rid of his political opponents by dismissing their ministries, labelling them as anti-state traitors, and using 
violence against them, the opposition leaders had finally succeeded to put enough pressure on the government for the acceptance of their demands, which would not have been possible without submerging mutual differences and striking an alliance at the cost of their party manifesto and agenda.

\subsection{The Pakistan National Alliance (PNA): The beginning of the end}

From promulgation of the 1973 Constitution till the year1976, the relations between the government and the opposition remained far from being cordial, yet the system was running despite the bumpy ground on which it had to run (Waseem, 1989). The ban on NAP had been re-imposed and its leadership was arrested on charges of treason. All this naturally created a stir in national politics but not to the extent of an uncontrollable nature. However, the political scenario changed significantly with Bhutto's call for fresh elections in 1977 (Wynbrandt, 2009). This was much in line with the wishes of the opposition and to an extent of the general masses who had been demanding the holding of a fresh election in the country. Bhutto's position at the time was strong but in actual terms, he was facing many problems within his party as many of the top leaders of PPP had left the party due to his authoritarian behaviour and dictatorial tendencies (Wolpert, 1991). In this unhealthy political situation, Z. A. Bhutto announced the schedule of the general elections on January 7. The elections were to be held on March 7 and 10 for the National and Provincial Assemblies respectively (Hayes, 1986). To achieve an overwhelming victory and a larger majority in the 1977 general elections, Bhutto amended the Constitution to prohibit members of the defunct NAP from contesting the election (Raza, 2001).

After the announcement about holding of a fresh general election, the opposition parties held a meeting on January 10, 1977 in Lahore and formed an electoral alliance known as the Pakistan National Alliance (PNA) on January 11, 1977 to counter the might of the PPP. The alliance decided to contest the election from a single platform (Khan, 2001). This new alliance was as unnatural as other alliances between the opposition parties in the past. Seemingly, there was no other objective of the alliance except the ouster of Bhutto from power. It was comprised of the following nine political parties: Pakistan Muslim League, Tehrik-i-Istiqlal, Jammat-i-Islami, Jamiat-ul-Ulama Islam, Jamiat-ul-Ulama Pakistan, National Democratic Party, Pakistan Democratic Party, Khaksar Tehrik, and Azad Kashmir Muslim Conference. Maulana Mufti Mahmud was unanimously elected President of the PNA and Rafique Ahamd Bajwa of JUP and Nawabzada Nasrullah Khan of PDP were elected as Secretary-General and Vice-President respectively. The purpose of forming this united opposition front was to defeat the PPP in the general elections (Nizami, 2007).

Pakistan National Alliance declared as its objectives the elimination of un-Islamic institutions from the country, handing over the lands to their original and rightful owners, the release of NAP leaders from prisons, disbanding of the Hyderabad Tribunal, which was to hear the cases of the imprisoned opposition leaders including Wali Khan, and withdrawal of the armed forces form Balochistan. The implementation of Islam was its primary slogan during the election campaign and its leadership promised to enforce Islamic laws "Nizam-e-Mustafa" and the Sharia (Shehab, 1990; Zahoor, 2017). In a country like Pakistan religion could be used as an effective tool to exploit the emotional attachment of the people with their faith and to give an extra fillip to the movement against the incumbent government.

During the election campaign, Bhutto once again raised the slogan of Roti, Kapra Aur Makan 
to retain the support of the majority belonging to the lower and middle class. He was fully confident of his victory and used every means to strengthen his position by assigning the task of making favorable propaganda to the Ministry of Information and Broadcasting in support of his party program and election manifesto (White Paper, 1978). He accused the alliance of opposition parties as a nexus to block the way of progress and prosperity and termed its member parties as to the amalgamation of divergent elements that had come together for the only purpose to defeat the ruling party. He called them traitors and anti-Pakistan who had opposed the creation of Pakistan (Khan, 1977).

The PNA leaders, Maulana Noorani of JUP, Sherbaz Mazari of the NDP, Mian Tufail of JI, and Asghar Khan of TI divided themselves into groups and launched a country-wide campaign, addressing large gatherings to win public support (Khan, 2005). Keeping in view the popularity of their movement, the leaders of PNA were confident about their victory in the polls (Mahmood, 1984). But the result of the election was shocking for the PNA, winning only 36 seats throughout the country while PPP secured a sweeping majority, winning 155 seats out of a total of 200 seats in the National Assembly (Khan, 2005).

The election results were rejected by the PNA and its leadership accused the ruling PPP of rigging the polls on a massive scale. The PNA Central Committee decided to boycott the elections of the provincial assemblies to be held on March 10, 1977. They also launched a nationwide protest and announced their resignation from the seats of the National Assembly. They demanded the immediate resignation of the Electoral Commission, the Prime Minister, and the re-election of the National Assembly under the supervision of the army (Dawn, 1977). The PNA started its movement by the name of 'Tehrik-i-Nizam-e-Mustafa' and pledged for the enforcement of the Islamic Law or Sharia in the country. The response of the masses to the calls for strike made by the PNA leaders was encouraging and there was a complete shutter down in almost every big city. This state of political turmoil and chaos continued in the country for about four months and on many occasions, the army was called by the government to restore law and order in big cities (Ibrahim \& Mussarat, 2015).

This political confusion in Pakistan got international consideration. In particular, the Muslim world showed its concern and pressurized the Pakistan Government for the restoration of normalcy through dialogue with the opposition parties. The efforts of Saudi Ambassador, Riaz ul Khateeb, Sheikh Zayed bin Al-Nahyan of UAE, and King Khalid of Saudi Arabia were instrumental in breaking the deadlock between the Government and the PNA leaders. (Qureshi, 1993) Ultimately, this political turmoil in the country compelled Bhutto to enter a dialogue with the PNA leadership. Three rounds of negotiation were held and the drama of making and breaking of agreements continued. Many letters were exchanged between Bhutto and Mufti Mahmud. Bhutto hoped that the Maulana would give a positive response and would enter in dialogue to find a democratic solution to the problem peacefully. But the PNA leaders after their consultation in the Alliance Council Meeting at Lahore on March 22-23 rejected the offer of dialogue (Mahmud, 1977).

The meeting between the ruling party leaders and the leaders of the PNA, however, did take place and on July 1, 1977, Bhutto accepted the demand for fresh elections. It was offered that a caretaker council for elections would be formed with Bhutto as its Chairman without giving it any constitutional status. But the proposal was rejected and the date for the next meeting was fixed at July 5, 1977 (Ziring, 2003). Unfortunately, that meeting could not be held as on the night of July 5 the army intervened, General Zia-ul-Haq declared Martial Law. Many issues 
were left unanswered and Bhutto's government was overthrown. The PNA welcomed the military coup (Zahra, 2020).

Bhutto accused the United States of supporting the PNA movement to oust him and referred to Pakistan's agreement with France on nuclear reprocessing plants as one of the reasons for the differences with the United States (Sherpao, 2017). Bhutto believed that the unity of the PNA was not a "desi" (local) rather an international conspiracy against Pakistan. Kausar Niazi, who was a federal minister in the Bhutto cabinet, later, pointed out that the army generals had organized their whole strategy against the PPP based on the PNA demands. The military junta got involved in a conspiracy with the leaders of PNA, particularly Asghar Khan and Zia played an important role in preventing the opposition from concluding a deal with Bhutto (Dawn, 1977). Irrespective of its causes, Bhutto was deposed and Pakistan thus had to endure the longest period of military rule.

\section{Conclusion}

The analysis of the political alliances during the rule of Zulfiqar Ali Bhutto confirms the theory that political alliances are made to gain access to power but the results of these alliances and accords were both productive and counterproductive. They eventually led to regression and antagonism but in the process, they also produced some temporary positive results. Primarily, the alliances such as the NAP-JUI coalition and the Tripartite Agreement on the constitutional draft led to political stability, facilitated the adoption of the 1973 Constitution, and the formation of the NAP-JUI coalition ministries in NWFP and Balochistan.

The alliances, between the opposition parties and between the ruling party with Abdul Qayyum Khan had one striking similarity; both were unnatural and made compromises on principles and party manifesto. Like the ideological differences between NAP and JUI, Bhutto also had no ideological and political agreement with Abdul Qayyum Khan. It was another example of alliances aimed at curbing rival political parties and leadership. Perhaps bringing Qayyum Khan into his cabinet was the beginning of a process that led to confrontationist power politics and the ultimate end of the political harmony that prevailed at the time of the drafting of the 1973 Constitution.

Overall, this era is regarded as popular and democratic, marked by progress in various fields to strengthen civilian governments. However, Bhutto's relations with regional leaders were far from being wise and prudent. The politicians that could align to strengthen his position, turned against him, and formed alliances of disruptive nature in the form of UDF and PNA only to oust him from his position.

We are not good at learning a lesson from the history but history is good at punishing those who ignore their past. In democracies, there may be differences of opinion about the timeline and methods of achieving goals and even the goals itself but all political parties usually have two common goals; the welfare of the masses and the stability of the country. If a neutral observer or analyst were to examine the role of the political parties in Pakistan, the obvious conclusion would be that the overall performance was poor. Most political leaders and their parties remained deeply involved in power politics at the expense of the people as well as national interest. Nonetheless, the alliances formed at different times in the history of Pakistan were a practical manifestation of this general tendency prevailing among the political leadership of Pakistan. 


\section{References}

Ahmad, G. (1990). Phir martial law agaya (Urdu). Jang Publishers.

Ahmad, M. (1993). Jamiyyat Ulema-i-Pakistan: 1948-1979. National Institute of Historical and Cultural Research. https://www.worldcat.org/title/jamiyyat-ulama-i-pakistan1948-1979/oclc/30739261

Amin, A. (1974). Pakistan and the challenge of history. University Books.

Amin, T. (1988). Ethno-national movements of Pakistan. Institute of Policy Studies Islamabad.

Alvi, N. (2016). Rise and fall of the first political government of Balochistan (Sardar Atta Ullah Khan Mengal's government). Journal of the Punjab University Historical Society, 29(1),

133-134. http://pu.edu.pk/images/journal/HistoryPStudies/PDF_Files/10Paper-Vol-29-No-1June-2016.pdf

Anjum, T. H. (1993). Pakistan: Tarikh-o-Sayasy Jaisey (Urdu). Nazir Ahmad Publishers.

Baxter, C. (1974). Constitution-making: The development of federalism in Pakistan. Asian Survey, 14(12), 1074-1085. https://doi.org/10.2307/2643201

Burki, S. J. (1988). Pakistan under Bhutto 1971-1977. Palgrave Macmillan.

Dawn. (1972, March 7). Majority parties to form Govts in NWFP, Baluchistan, interim Constitution by April 17.

Dawn. (1972, March 8). NAP not to join central cabinet right now: Wali \& PPP-NAP-JUI accord welcome.

Dawn. (1972, April 5). The formula for interim Constitution: Tripartite moot on April 10.

Dawn. (1973, June 29). NAP leaders hold 4 hours talks with President.

Dawn. (1977, January 30). Bhutto rebutted PNA leaders charges.

Dawn. (1977, February 17). Peshawar meeting.

Firdausi, Z. A. (1988). Eagle over Pakistan. Book Traders.

Haidar, A. (1996). Bhutto Trial. National Commission on History and Culture.

Hassan, M. U. (ND). Hakomat-o-sayisat 1947-1990. New Palace.

Hayes, L. D. (1986). The struggle for legitimacy in Pakistan. Vanguard Books.

Hussain, A. (2008). Politics of alliance in Pakistan: 1954-1999. Unpublished Ph.D. Thesis. National Institute of Pakistan Study Centre. Quaid-e-Azam University.

Hussain, M. (2000). The mirage of power: An inquiry into the Bhutto years 1971-77. Oxford University.

Ibrahim, M., \& Mussarat, R. (2015). Electoral politics: A case study of Pakistan (1947-1985). Journal of Public Administration and Governance, 5(1), 80. http://doi.org/10.5296/ jpag.v5i1

Kadima, D. (2014). An introduction to the politics of party alliances and coalitions in sociallydivided Africa. Journal of African Elections, 13 (1), 1-24. http://doi.org/10.20940/JAE/2014/v13i1a1

Kaushik, S. N. (1985). Pakistan under Bhutto's leadership. Uppal Publishing.

Khan, K. A. Q. (1977, November 17). Daily situation report [Unpublished Manuscript]. Directorate of Archives \& Public Libraries, Government of Khyber Pakhtunkhwa, Peshawar (No. 257, Special Branch NWFP, List, III, Serial No. 33, Bundle No. 3, 85).

Khan, A., Khan, T. M., \& Rehman, A. U. (2017). Government-opposition relations amidst the provincial autonomy during the Bhutto regime. Journal of the Research Society of Pakistan, 54(2), 41-52. http://pu.edu.pk/images/journal/history/PDF-FILES/04Paper_54_2_17.pdf 
Khan, H. (2002). Constitutional and political history of Pakistan, ( $2^{\text {nd }}$ ed.) Oxford University. Khan, J. D. (2001). Pakistan: Leadership challenges ( $2^{\text {nd }}$ ed.) Oxford University.

Khan, M. A. (2005). We've learnt nothing from history: Pakistan politics and military power. Oxford University.

Kumar, S. (1978). The new Pakistan. Vikas Publishers.

Leiserson, M. (1968). Factions and coalition in one-party Japan: An interpretation based on the Theory of Games. American Political Review, 62 (3), 770-787. https://doi.org/10.2307/1953429

Mahmood, S. (1984). A political study of Pakistan. Educational Book Company.

Mahmood, S. (2000). Pakistan: Political roots and development 1947-1999. Oxford University.

Malik, R. Z. (2020). Parliamentary system and framing of 1973 Constitution: Contest between government and opposition inside the National Assembly. Pakistan Perspectives, 25 (1), 25-47. https://journal.psc.edu.pk/index.php/pp/article/view/385/382

Mahmud, M. M. (1972, March 10) "Daily Situation Report”. [Unpublished Manuscript] Directorate of Archives \& Public Library, Government of Khyber Pakhtunkhwa, Peshawar. (No. 56. Special Branch NWFP, List. III, Serial No. 162. Bundle No. 10).

Mahmud, M. M. (1977, March 25). “Extract. 1877-1879”. [Unpublished Manuscript]. Directorate of Archives \& Public Libraries, Government of Khyber Pakhtunkhwa, Peshawar. (Bundle No. 10, Serial No. 160, List III, Special Branch NWFP).

Mazari, S. (1999). A journey to disillusionment. Oxford University.

Niaz, I. (2010). The culture of power and governance of Pakistan 1947-2008. Oxford University.

Nizami, Q. (2007). Jo Dheka Jo Suna (Urdu). Jahangira Books.

Pirzada, S. A. S. (2000). The politics of Jamiat-e-Ulema-e-Islam Pakistan: 1971-77. Oxford University.

Bajwa, R. (1977, March 10). Press conference of Secretary-General of PNA. Dawn, Karachi. Qureshi, A. A. (1993). Zulfiqar Ali Bhutto: Afwah aur haqeeqat (Urdu). Frontier Post.

Raza, R. (1997). Zulfiqar Ali Bhutto and Pakistan 1967-77. Oxford University.

Raza, R. (2001). Pakistan in perspective 1947-1997 (ed). Oxford University.

Sayeed, K. B. (1985). Politics in Pakistan: The nature and direction of change. Praeger.

Shehab, P. R. (1990). Fifty years of Pakistan. Maqbool Academy.

Shah. S. F., \& Khan, M. Z. (2012). Zulfiqar Ali Bhutto regime and growth of the Baloch nationalism in the 1970s. Global Journal of Human Social Science. 12 (7). 61-68. https://socialscienceresearch.org/index.php/GJHSS/article/view/339

Sherpao, A. A. K. (2017, December 6). Personal Communication with Aftab Ahmad Khan Sherpao, is the Chairperson of the centre-left Pashtuns nationalist Qaumi Watan Party, brother of the late Hayat Sherpao (a former governor of the then NWFP and president of provincial branch of PPP), and a former member of the Pakistan People's Party Parliamentarian.

Siddique, A. (2014). The Pashtun question the unresolved key to the future of Pakistan and Afghanistan. Oxford University.

Sufi, J. K. (2017, December 6). Personal Communication with Juma Khan Sufi. He belonged to NAP, left for Kabul during the rule of Zulfiqar Ali Bhutto rule.

Tasneem, S. (2013). Working relationship between central and provincial governments in Pakistan (1971-77). International Journal of Humanities and Social Science, 3(17), 196-204. https://pdf4pro.com/view/working-relationship-between-central-andprovincial-56ed 34. html 
The Pakistan Times. (1973, March 25). Majority parties formation of Govts in NWFP \& Baluchistan Provinces.

Wynbrandt, J. (2009). A brief history of Pakistan. Insobase Publishing.

Waseem, M. (1989). Politics and the state in Pakistan. Progressive.

White Paper (August 1978). The misuse of media. Issues by Zia Government.

William, L.F. R. (1975). Pakistan under challenges. Stacey International.

Wolpert, S. (1991). Zulfi Bhutto of Pakistan: His life and times. Oxford University.

Wriggins, W. H. (1975). Pakistan in transition. University of Islamabad.

Zahra, U. (2020). Political assassinations in Pakistan with Special reference to the mystery of the murder of Hayat Muhammad Khan Sherpao, 1975. Pakistan Perspectives, 25(2). 105-122. https://journal.psc.edu.pk/index.php/pp/article/view/404

Zahoor, M. (2017). Zulfiqar Ali Bhutto: Political behaviour and ouster from power. Journal of the Punjab University Historical Society, 5(2), 99-110. http://pu.edu.pk/images/journal/HistoryPStudies/PDF_Files/10_V-30-No2Dec17.pdf

Ziring, L. (2003). Pakistan in the twentieth century: A political study. Oxford University. 